\title{
Introduction: Judicialization of social problems and governance of security in comparative perspectives
}

ONATI SOCiO-Legal SERIES Volume 11, Issue 6 (2021), 1260-1272: JudicializATION OF SOCiAL PROBLEMS AND GOVERNANCE OF SECURITY IN COMPARATIVE PERSPECTIVES

DOI LINK: HTTPS://DOI.ORG/10.35295/OSLS.IISL/0000-0000-0000-1247

ReCEIVED 15 NOVEMBER 2021, ACCEPTED 16 NOVEMBER 2021, VerSION OF ReCORD Published 01 DECEMBER 2021

\author{
JOAO VELLOSO* \\ VÍVIAN FERREIRA PAES*
}

\section{Abstract}

This special issue is composed by six papers whose first versions were presented at the Oñati workshop Social Control, Judicialization of Social Problems and Governance of Security in Comparative Perspectives held at the IISL in July 2019. They are preceded by this introduction, where we contextualize the development of social control studies, pointing how they were originally framed as criminalization in the Global North and how the new millennium brought us an increasing number of studies discussing both criminalizations (in the plural!) and forms of judicialization and governance operating through regulatory, administrative, civil and hybrid legal regimes. By putting together articles about different contexts and jurisdictions into conversation, we hope to illuminate how legal orders (State-based or not) are mobilized to govern security and social problems, creating more nuanced categories and analytical tools to help thinking and resisting to penalization processes of any kind, anywhere, anytime.

\section{Key words}

Judicialization; criminalization; social control; governance

\section{Resumen}

Este número especial está compuesto por seis trabajos cuyas primeras versiones fueron presentadas en el workshop de Oñati Social Control, Judicialization of Social Problems and Governance of Security in Comparative Perspectives, celebrado en el IISJ en julio de 2019. Están precedidos por esta introducción, donde contextualizamos el desarrollo de los estudios de control social, señalando cómo se enmarcaron originalmente como

\footnotetext{
* Associate Professor, Faculty of Law - Common Law Section, University of Ottawa, Canada. Email address: Joao.Velloso@uottawa.ca

* Department of Public Security, Faculty of Law, Universidade Federal Fluminense, Niterói, Brazil. Email address: vivianfpaes@yahoo.com.br
} 
criminalización en el Norte Global y cómo el nuevo milenio nos trajo un número creciente de estudios que debaten tanto sobre criminalizaciones (¡en plural!) como sobre formas de judicialización y gobernanza que operan a través de regímenes legales regulatorios, administrativos, civiles e híbridos. Al poner en conversación artículos sobre diferentes contextos y jurisdicciones, esperamos arrojar luz sobre cómo se movilizan los órdenes legales (basados en el Estado o no) para gobernar los problemas sociales y de seguridad, creando categorías más matizadas y herramientas analíticas que ayuden a pensar y resistir a los procesos de penalización de cualquier tipo, en cualquier lugar y en cualquier momento.

\section{Palabras clave}

Judicialización; criminalización; control social; gobernanza 


\section{Table of contents}

1. Introduction

2. Reopening the black box of social control: Criminalizations and beyond criminalization

3. The essays

1266

4. Conclusion 1268

References.

1268 


\section{Introduction}

This special issue has its origins in the Oñati workshop Social Control, Judicialization of Social Problems and Governance of Security in Comparative Perspectives held at the IISL in July 2019, organized by us and have counted with the participation of eighteen scholars from eight different countries (Global North and South) and various academic backgrounds (law, sociology, criminology, anthropology, political science, and urban studies). The workshop was prompted by the relative success of the homonymous triple session we organized within the Research Committee in Sociology of Law (RCSL) at the XIX ISA World Congress of Sociology in Toronto 2018. Back in 2017, we felt there was a lack of academic forums to nuance the legal technicalities (Valverde 2009) and legal sensibilities (Geertz 2000) of social control processes. Studies on social control and penalisation were booming in a very rich and diverse way, but they were often fragmented, and still are, in sessions more related to empirical topics (e.g. police, immigration, homelessness, mental health, drugs, Latin America, Africa, etc.) or being the other paper in a panel dominated by criminal law, criminal justice or criminal punishment. At the time, we simply wanted to have a session on social control that was not limited to processes of criminalization framed from a Global North perspective and that would also prioritize sociology of law and socio-legal approaches on the practices of legal institutions when responding to social problems or dealing with security projects. It was not about social control as a particular form of criminalization, but criminalizations in the plural (Paes 2013) and other kinds of judicialization (Velloso 2013b), discussing how law was mobilized in such new and old modalities of social control (Paes and Ribeiro 2017). We were surprised by the demand for our session proposal at the ISA World Congress, as we received over forty propositions from twenty different countries. Scholars across the globe wanted to discuss and compare studies that tended to be framed as unrelated. They are not. That was the day we decided to organize the Oñati workshop and to continue the sessions within the RCSL. Our feeling is that this special issue is only the first of many to come on this topic.

\section{Reopening the black box of social control: Criminalizations and beyond criminalization}

The governance of security and social problems has changed substantially in the last decades, both by harshening criminal punishment (e.g. punitive turn, penal populism) and by widening the scope of penalization processes (e.g. shadow carceral state, Beckett and Murakawa 2012). Traditionally, most of democratic societies tend to manage security-related conflicts and "dangerous" populations through legal institutions anchored in the following liberal triad: legal rules, balanced rights and sanctions, being usually associated to criminal law and criminal trials. While criminalization is still the primary face of social control, an increasing number of scholars have been pointing to a variety of forms and processes of judicialization and penalization, either within criminal law regimes (e.g. preventive justice, Ashworth and Zedner 2014) or relying on regulatory, administrative, civil, or hybrid legal regimes (Beckett and Herbert 2008, 2010, Leerkes and Broeders 2010, Velloso 2013a, 2016, Macaulay 2013, Spivakovsky 2014, Oliver and Urda 2015, Calatayud 2016, Persak 2016, Zedner 2016, Carlson 2017, Fortin 2018, Calatayud et al. 2019, Brandariz 2021; among many others). 
Studies on judicialization of social problems and governance of security in comparative perspectives have traditionally focused primarily on one legal regime, namely criminal law, tending to "black box" 1 legal responses in a criminocentric (Velloso 2013b, Valverde 2014) and Global North way. This has been the case since the emergence of social control studies in the 1960s and 1970s (Becker 1963/1973, Robert 1973, Landreville 1986, Pfohl 1994). Social control studies usually take the social construction of crime and deviance (criminalization), as if criminal justice encompasses all forms of law and "penal institutions" (Foucault 2013, 2015). Studies in sociology of deviance or of crime and critical criminology played a key role in conceptualizing the ideas of criminalization and socio construction of crimes through a sequential interpretative chain that transforms everyday life events into abstract legal categories, and creating a less politically dangerous form of delinquency, as Foucault would add in Discipline and Punish (1975/1995). They were the best science we could get. Generally speaking, social sciences figured out how criminalization works after the labelling (Schur 1971, Becker 1973, Robert 1973), new criminology (Taylor et al. 1973) and Foucauldian contributions, black boxing the concept. After all, the matter was fairly settled and consensual at its core, at least in the Global North.

Obviously, we do not need to develop that much in this introduction that the internal complexity of the criminalization machine in the Global South and the Socialist Bloc at the time (1970s) was quite different than the black boxed concept of criminalization developed in the context of some "First World" countries. To imagine that the police in Latin America, Africa or the Socialist world would make crime as Ericson suggested in his seminal book (1981), or trying to find the panopticon or discipline in their prison systems, sounds hilarious today. ${ }^{2}$ For the good and for the bad, the internal complexity of social control was centered in the criminal justice system and the Global North. The concept of criminalization allowed a great progress in scholarship, including in the Global South, and led to more awareness to systemic issues, law reforms and social change. As the new criminology predicted, it helped "to create a society in which the facts of human diversity, whether personal, organic or social, are not subject to the power to criminalize" (Taylor et al. 1974, 282). However, it also occluded other internal complexities in social control, criminal justice based or not, limiting the possibilities of critical interventions and resistance.

Criminalization studies in the Global North changed a lot since Foucauldian contributions. Two important nuances emerged in the literature of the 1980s: 1) a new generation of studies on elite deviance centered on the legal responses to this type of delinquency (Lascoumes 1983, Shapiro 1984, Braithwaite 1984, Acosta 1988; among others), ${ }^{3}$ some of them building upon Foucault's distinction on "illegalities of property"

\footnotetext{
1 "An expression from sociology of science that refers to the way scientific and technical work is made invisible by its own success. When a machine runs efficiently, when a matter of fact is settled, one needs focus only on its inputs and outputs and not on its internal complexity. Thus, paradoxically, the more science and technology succeed, the more opaque and obscure they become" (Latour 1999, 304).

2 For instance, in Brazil, criminalization processes are still substantially different even in democratic times (Paes 2013, Paes and Ribeiro 2017). In the 1970s it was more a matter of totalitarism than making crime.

${ }^{3}$ The publication of the uncut version of White-Collar Crime (Sutherland 1983) and Illegal but Not Criminal (Conklin 1977), somehow anticipated these new generation of studies, but these books were still focused mainly on the causes of delinquency and not on the social reaction processes.
} 
and "illegalities of rights" with the first related to the production of delinquency and the second being managed by specialized judicial circuits instead of criminal justice (Foucault 1995, 87 ss.); and 2) Clifford Shearing's studies on private security (Shearing and Stenning 1982) and his critique of the notion of crime and call to decriminalize criminology (Shearing 1989), which also opened a great door to explore the legal responses in other judicial circuits, but without necessarily associating them with particular kinds of illegalities. Shearing's proposition was much more radical, as he was arguing already in the 1980s that the stuff of criminology and of social control was not about crime nor restricted to it. Not by surprise, there was a proliferation of studies on criminalization in a broader sense, that is, on legal responses of any kind (civil, administrative, criminal or regulatory). ${ }^{4}$

These two intellectual developments from the 1980s are not sufficient to explain the sustained emergency of studies on social control beyond criminal justice in the 1990s and their boom in the new millennium. The world has changed enormously after the Cold War and certain ways of doing social control became more apparent and recurrent. We are far from pretending to cover all the nuances and the different forms of judicialization at the turn of the millennium, but there are at least three major research areas that deserve to be mentioned. First, the control of urban disorders in contexts influenced by the "broken window theory" (Kelling and Wilson 1982, Kelling and Coles 1996), as in most cases by-laws and ordinances or new regulations were mobilized along with criminal justice or as a punitive alternative to it. Second, immigration control and (re)securitization of borders in a more globalized and multilateral world. The social control of migrants regarding their particular status is a matter of administrative law or State bureaucracy in most of Western countries, if not across the globe. And third, the War on Terror, especially after the 9/11 Attacks (2001). The reactions to the 9/11 gave birth to a rich literature on administrative law, notably the of use military law and exceptional regimes, that were already in the hundreds of references by 2005, thousands ten years later and by solid five digits nowadays. The bottom line is that the empirical dimension was increasingly available. The judicialization of social problems and governance of security were everywhere, mobilizing legal regimes of any kind, some of them barely legal or only temporally valid (Steyn 2004, Pue et al. 2015), and countless studies followed in the Global North and South.

In addition to these research areas, Post-Colonial studies in social control (Agozino 2003, 2004, Blagg and Thalia 2019), Southern criminologies (Melossi et al. 2011, Carrington et al. 2016, 2018, 2019) and epistemologies of the South (Santos 2014, Comaroff and Comaroff 2016) became more visible to the Global North, providing even more insights about how law is mobilized in various jurisdictions. Finally, we could also consider recent empirical developments regarding the decriminalization of cannabis and other substances in different countries and dynamics of social control during the pandemic. Usually, the decriminalization of certain is paired with regulations that governs the production, commercialization and consumption; "legal drugs" are still controlled substances, just not controlled by criminal law or by legal orders anchored in illegal markets (Rocher 1988,

\footnotetext{
${ }^{4}$ Adapted from Susan Shapiro's clarification in Wayward Capitalists: “The term 'prosecution' is used in this context to describe the decision to take formal legal action of any kind (civil, administrative, or criminal) against securities violators. It is not used here in its more narrow and common law usage pertaining exclusively to criminal dispositions" $(1984,147)$.
} 
2019, Daudelin and Ratton 2018). Regarding the still ongoing pandemic, one can argue that we experienced a mix of the three areas mentioned above with a health law spin to them: spatial control through regulations, strict border control, (over)use of questionable special regimes and emergency powers. We are very far from achieving a saturation point on what is judicialization of social problems and governance of security. We still do not fully understand how social control operates, but we do know that is not about one particular kind of criminalization. There are a lot of things going on in the Global South and the Global North, within and beyond criminal law. In fact, we are not opening the black box of social control. The many boxes were already opened by others. We are just facilitating the debate through sessions, workshops and this special issue.

Comparative perspectives is imperative to this collective enterprise of trying to figure out how social control operates. We take a comparative approach in a very anthropological sense. It is not a matter of looking for the similar or seeking patterns. Quite the contrary, it is about creating strangeness, contrasts, nuances in order to better understand what is happening in our own studies and contexts. As Malinowski argued a long time ago, on his seminal book about an island far, far away: "In grasping the essential outlook of others, (...) we cannot but help widening our own" (Malinowski 1922, 518). We need to grasp how criminalizations, in the plural, work and how legal regimes along, beyond and in addition to criminal law work. Without having at least some sense of this, our own studies on social control are fated to be narrow, limited and sometimes simply wrong. As Geertz suggests: "Anthropology, or at least interpretive anthropology, [and we would say any interpretative social science $]^{5}$ is a science whose progress is marked less by a perfection of consensus than by a refinement of debate. What gets better is the precision with which we vex each other" (Geertz 1973, 29). In this sense, the main contribution of the Oñati workshop that led to this special issue and this special issue itself is a refinement of the debate on the judicialization of social problems and governance of security: our goal is to nuance categories, strategies, tactics, legal technicalities and legal sensibilities used penalization processes of any kind, anywhere, anytime.

\section{The essays}

The first contribution is Gema Varona's Defensive urbanism and local governance: Perspectives from the Basque Country. Dr. Varona discusses the origins and development of defense urbanism as an issue undissociated from particular conceptions of security and ordering informed by broken windows theory. More than an architectural design increasingly present in our cities, defensive urbanism is framed as a legal practice. Focusing on the Basque Country, she analyses the uses of administrative law by local jurisdictions, as they do not have competence to enact criminal law, and the rationales mobilized in the uses of ordinances; which are not only about security. She also discusses the problematic escalation of sanctions and the hybridization between administrative offences and criminal law through "the crime of disobedience of authority", opening even more possibilities to the stigmatization and harassment of street populations.

In the second essay of the special issue, "Human rights" in dispute: State violence and demands for justice in a comparative perspective, Lucia Eilbaum discusses the disputes around the category "human rights" in Rio de Janeiro (Brazil) and Buenos Aires

${ }^{5}$ Law is a social science. 
(Argentina) in the context of demands for rights and justice in cases of police and State violence. Dr. Eilbaum looks into the local, social and political contexts of the enunciation and use of the human rights category, analyzing the reactions to the murder of Marielle Franco to explore the tensions and antagonisms in the mobilization of the category, the attacks to human rights (objectively and discursively), the appropriation of the category by certain groups (including police officers), the particularisation of human rights and the moralisation regarding whom should have access to such demands for rights and justice.

The third article, Regulating social spaces of everyday life: The bottom-up codification of a behavioural norm in a Dutch municipal bylaw, written by Danielle Chevalier, is also about the regulation of urban spaces through by-laws and ordinances. However, any similarities with the first article stops there. Dr. Chevalier invites you to think about how urban spaces are regulated, who is being regulated and who is behind the regulating through the study of a case about a small playground in downtown Amsterdam. Some residents requested the city to enact a ban on using cannabis products in and nearby the playground. The city refused, supported by other residents and the initial petitioners went up to the Dutch supreme court in administrative law seeking the ban. As you may anticipate, the questions about how social control, who is being controlled and who are the moral entrepreneurs may take a quite different direction, or not (!), in this case. No spoilers here. You will have to read her article to get of the end of it, but as she argues: "the contention over the legal norm represents the power relation in that space" [the playground and its neighborhood].

The fourth article, Criminal policy and technology: Electronic monitoring in Brazil and Argentina in a comparative perspective by Cristina Zackseski, in Portuguese, is a methodical comparative analysis of the legality and discourses on the uses of electronic monitoring in Brazil and Argentina. Dr. Zackseski scrutinizes the introduction of this dispositif (Foucault 1980, 1995, Garland 2014) in both countries and how it is related to their broader criminal policies. As Foucault would put it: "The apparatus [dispositif] itself is the system of relations that can be established between these elements" (Foucault 1980, 194). She identifies and discusses ten elements that translates the main ideas around electronic monitoring, confronting them with the empirical data on the functioning of the criminal justice system in Brazil and Argentina.

Elizabete Albernaz and Lenin Pires examine the complex relations between violence, mobility and inequalities in "Places you shouldn't go to": (Im)mobility, violence and democracy in Brazil and South Africa. They do a South-South comparative analysis focusing on two particular contexts: the Muzema favela in Rio de Janeiro (Brazil), a slum neighbourhood controlled by para-military groups (milícias); and the Maboneng District in Johannesburg (South Africa), a revitalized precinct with security projects governed mostly by the private sector. Dr. Albernaz and Dr. Pires provide insights into the nexus between urban mobility and security, the oppositions safe/unsafe and legal/illegal, and how non state actors play a role in social control and governance of security. Their contribution reminds us that the State is indeed a very porous entity, at least its created margins, with complex everyday relations and compositions with marginal legal orders (Rocher 2019) and powerful market forces. In this sense, they propose the idea of 
"persistent precariousness" as an analytical tool to help exploring these intricate forms of governance of security in Rio de Janeiro and Johannesburg.

Last but not the least, Daniel Ganem Misse's Police performance and violent crime in Rio de Janeiro between 2007 and 2017 nuances criminalization of violent crimes, notably homicides, through the analysis performance-related pay policies available to the Rio de Janeiro military police (the public police responsible for ostensive policing). Dr. Ganem Misse takes a mixed-methods approach, quantitative and qualitative, analysing criminal justice indicators before, during and after the implementation of different performancerelated pay policies and interviewing key actors. Financial incentives linked to predetermined targets, Integrated Targets System (Sistema Integrado de Metas, SIM) being the main available program, clearly affects policing and how police officers make crime. However, this does not mean only prioritizing certain types of police intervention to show productivity, but also pursuing a reduction of key police records. Interestingly, the data suggest that the SIM is becoming a paid bonus for officers from police districts located in areas controlled by milícias (para-military groups); which may raise questions about the association between public policing and para-military groups ${ }^{6}$ and the registration of homicides or other violent crimes in these areas of the city.

\section{Conclusion}

Together, these six articles provide a small glimpse in the variety of ways of doing social control today and their internal complexities. They do provide some answers to local forms of judicialization of social problems and governance of security, but most importantly they help us to think and ask even more questions. We are very grateful to all contributing authors, reviewers and the journal, specially Leire Kortabarria. We were one of the last Oñati workshops prior to the COVID-19 pandemic and most of the making of this special issue occurred during difficult circumstances. This special issue would not be available without the hard work, diligence, and patience of all of them.

\section{References}

Acosta, F., 1988. À propos des illégalismes privilégiés: Réflexions conceptuelles et mise en contexte. Criminologie [online], 21(1), 7-34. Available from: https://doi.org/10.7202/017256ar [Access 16 November 2021].

Agozino, B., 2003. Counter-Colonial Criminology: A Critique of Imperialist Reason. London: Pluto.

Agozino, B., 2004. Imperialism, crime and criminology: Towards the decolonisation of criminology. Crime, Law and Social Change [online], 41, 343-358. Available from: https://doi.org/10.1023/B:CRIS.0000025766.99876.4c [Access 16 November 2021].

Ashworth, A., and Zedner, L., 2014. Preventive justice. Oxford University Press.

Becker, H., 1973. Outsiders: Studies in the Sociology of Deviance. New York: Free Press. (Originally published in 1963).

\footnotetext{
${ }^{6}$ Other studies, Parliamentary Inquiry Commissions and judicial investigations already documented the presence of acting and former police officers in the ranks of milícias.
} 
Beckett, K., and Herbert, S., 2008. Dealing with disorder: Social control in the postindustrial city. Theoretical Criminology, 12(1), 5-30.

Beckett, K., and Herbert, S., 2010. Penal boundaries: Banishment and the expansion of punishment. Law \& Social Inquiry, 35(1), 1-38.

Beckett, K., and Murakawa, N., 2012. Mapping the shadow carceral state: Toward an institutionally capacious approach to punishment. Theoretical Criminology, 16(2), 221-244.

Blagg, H., and Thalia, A., 2019. Decolonising Criminology. London: Palgrave Macmillan.

Braithwaite, J., 1984. Corporate Crime in the Pharmaceutical Industry. London: Routledge.

Brandariz, J.A., 2021. An expanded analytical gaze on penal power: Border criminology and punitiveness. International Journal for Crime, Justice and Social Democracy [online], 10(2), 99-112. Available from: https://doi.org/10.5204/ijcjsd.1659 [Access 16 November 2021].

Calatayud, M.M., 2016. Punitive decriminalisation? The repression of political dissent through administrative law and nuisance ordinances in Spain. In: N. Persak, ed., Regulation and Social Control of Incivilities. London: Routledge, 69-88.

Calatayud, M.M., González-Sánchez, I., and Brandariz, J.A., 2019. Editors' Introduction: Policing the Protest Cycle of the 2010s. Social Justice, 46(2/3), 1-27.

Carlson, J., 2017. The hidden arm of the law: examining administrative justice in gun carry licensing. Law \& Society Review, 51(2), 346-378.

Carrington, K., et al., 2019. Southern Criminology. New York: Routledge.

Carrington, K., et al., eds., 2018. The Palgrave Handbook of Criminology and the Global South. London: Palgrave.

Carrington, K., Hogg, R., and Sozzo, M., 2016. Southern criminology. British Journal of Criminology [online], 56(1), 1-20. Available from: https://doi.org/10.1093/bjc/azv083 [Access 16 November 2021].

Comaroff, J., and Comaroff, J.L., 2016. Theory from the south, or, How Euro-America is Evolving toward Africa. London: Routledge.

Conklin, J.E., 1977. Illegal but Not Criminal. Hoboken: Prentice Hall.

Daudelin, J., and Ratton, J.L., 2018. Illegal Markets, Violence, and Inequality: Evidence from a Brazilian Metropolis. Cham: Springer International.

Ericson, R.V., 1981. Making Crime: A Study of Detective Work. Oxford: Butterworths.

Fortin, V., 2018. The Control of public spaces in Montreal in times of managerial justice. Champ pénal/Penal field [online], vol. 15. Available from: https://doi.org/10.4000/champpenal.10115 [Access 16 November 2021].

Foucault, M., 1980. Power/knowledge: Selected Interviews and Other Writings, 1972-1977. New York: Pantheon Books.

Foucault, M., 1995. Discipline and Punish: The Birth of Prison. Trans.: A. Sheridan. New York: Vintage Books. (Originally published in 1975). 
Foucault, M., 2013. La societé punitive: Cours au Collège de France (1972-1973). Paris: Gallimard.

Foucault, M., 2015. Théories et institutions pénales: Cours au Collège de France (1971-1972). Paris: Gallimard.

Garland, D., 2014. What is a "history of the present"? On Foucault's genealogies and their critical preconditions. Punishment $\mathcal{E}$ Society, 16(4), 365-384.

Geertz, C., 1973. The Interpretation of Cultures: Selected Essays. New York: Basic Books.

Geertz, C., 2000. Local Knowledge: Further Essays in Interpretive Anthropology. $3^{\text {rd }}$ ed. New York: Basic Books.

Kelling, G.L., and Coles, C.M., 1996. Fixing Broken Windows: Restoring Order and Reducing Crime in Our Communities. New York: Touchstone, Simon and Schuster.

Kelling, G.L., and Wilson, J.Q., 1982. Broken windows: The police and neighborhood safety. The Atlantic [online], 1 March. Available from:

https://www.theatlantic.com/magazine/archive/1982/03/broken-windows/304465/ [Access 16 November 2021].

Landreville, P., 1986. Évolution théorique en criminologie : L'histoire d'un cheminement, Criminologie [online], 19(1), 11-31. Available from: https://doi.org/10.7202/017224ar [Access 16 November 2021].

Lascoumes, P., 1983. Sanction des fautes ou gestion des illégalismes: L'hétérogénéisation du droit pénal. Revue interdisciplinaire d'études juridiques [online], 10, 125-156.

Available from: https://doi.org/10.3917/riej.010.0125 [Access 16 November 2021].

Latour, B., 1999. Pandora's Hope: Essays on the Reality of Science Studies. Cambridge, MA: Harvard University Press.

Leerkes, A., and Broeders, D., 2010. A case of mixed motives?: Formal and informal functions of administrative immigration detention. The British Journal of Criminology, 50(5), 830-850.

Macaulay, F., 2013. Modes of prison administration, control and governmentality in Latin America: Adoption, adaptation and hybridity. Conflict, Security $\mathcal{E}$ Development, 13(4), 361-392.

Malinowski, B., 1922. Argonauts of the Western Pacific. London: G. Routledge \& Kegan Paul.

Melossi, D., Sozzo, M., and Sparks, R., eds., 2011. Travels of the Criminal Question: Cultural Embeddedness and Diffusion. Oxford: Hart.

Oliver Olmo, P., and Urda Lozano, J.C., 2015. Bureau-repression: administrative sanction and social control in modern Spain. Oñati Socio-Legal Series [online], 5(5). Available from: https://opo.iisj.net/index.php/osls/article/view/418 [Access 16 November 2021].

Paes, V., 2013. Les rapports de la police judiciaire et du ministère public en France et au Brésil. Déviance et sociéte [online], 37(4), 415-439. Available from: https://doi.org/10.3917/ds.374.0415 [Access 16 November 2021]. 
Paes, V., and Ribeiro, L., 2017. Sociologia das práticas policiais e judiciais: novos atores, velhas práticas? Confluências, Revista interdisciplinar de sociologia e direito, 18(3), 0520.

Persak, N., ed., 2016. Regulation and Social Control of Incivilities. London: Routledge.

Pfohl, S.J., 1994. Images of Deviance and Social Control. New York: McGraw-Hill.

Pue, W.W., Diab, R., and Jackson, G., 2015. The Policing of Major Events in Canada: Lessons from Toronto's G20 and Vancouvers's Olympics. The Windsor Yearbook of Access to Justice [online], 32(2), 181. Available from: https://doi.org/10.22329/wyaj.v32i2.4708 [Access 16 November 2021].

Robert, P., 1973. La sociologie entre une criminologie de passage à l'acte et une criminologie de la réaction sociale. L'année sociologique, vol. 24, 441-504.

Rocher, G., 1988. Pour une sociologie des ordres juridiques. Cahiers de droit, 29(1), 91120.

Rocher, G., 2019. La pluralité des ordres juridiques. Revue générale de droit [online], 49(2), 443-479. Available from: https://doi.org/10.7202/1068526ar [Access 16 November 2021].

Santos, B. de S., 2014. Epistemologies of the South: Justice against Epistemicide. London: Routledge.

Schur, E., 1971. Labeling Deviant Behavior: Its Sociological Implications. New York: Harper \& Row.

Shapiro, S., 1984. Wayward Capitalists: Target of the Securities and Exchange Commission. New Haven: Yale University Press.

Shearing, C., 1989. Decriminalizing criminology: reflections on the literal and tropological meaning of the term. Canadian Journal of Criminology, 31(2), 169-178.

Shearing, C., and Stenning, P., 1982. Private security: Implications for social control. Social Problems, 30(5), 493-506.

Spivakovsky, C., 2014. From punishment to protection: Containing and controlling the lives of people with disabilities in human rights. Punishment $\mathcal{E}$ Society, 16(5), 560577.

Steyn, J., 2004. Guantanamo Bay: The Legal Black Hole. International \& Comparative Law Quarterly [online], 53(1), 1-15. Available from: https://doi.org/10.1093/iclq/53.1.1 [Access 16 November 2021].

Sutherland, E.W., 1983. White-Collar Crime. Westport: Praeger.

Taylor, Walton, P., and Young, J., 1973. New Criminology. London: Routledge.

Valverde, M., 2009. Jurisdiction and scale: Legal "technicalities" as resources for theory. Social and Legal Studies 18(2), 139-157.

Valverde, M., 2014. Studying the governance of crime and security: Space, time and jurisdiction. Criminology \& Criminal Justice, 14(4), 379-391. 
Velloso, J., 2013a. Au-delà de la criminalisation: l'immigration et les enjeux pour la criminologie. Criminologie [online], 46(1), 55-82. Available from: https://doi.org/10.7202/1015293ar [Access 16 November 2021].

Velloso, J., 2013b. Beyond criminocentric dogmatism: Mapping institutional forms of punishment in contemporary societies. Punishment \& Society, 15(2), 166-186.

Velloso, J., 2016. Le contrôle plurinormatif des gangs de rue: Contributions des études sur la délinquance des élites à la compréhension de la judiciarisation de la criminalité de rue. Criminologie [online], 49(1), 153-178. Available from: https://doi.org/10.7202/1036198ar [Access 16 November 2021].

Zedner, L., 2016. Penal subversions: When is a punishment not punishment, who decides and on what grounds? Theoretical Criminology, 20(1), 3-20. 